\title{
Meningkatkan Hasil Bimbingan TIK melalui Implementasi Project-Based Learning Berfasilitas Media Video Pembelajaran
}

\section{Supande Adi Putra ${ }^{1}$}

${ }^{1}$ SMP Negeri 3 Mengwi, Badung, Indonesia

\section{ART ICLE IN F O}

Article history:

Received August 26, 2021

Revised August 28, 2021

Accepted September 30, 2021

Available online December 25, 2021

Kata Kunci:

TIK, Project-Based Learning, Video Pembelajaran

Keywords:

ICT, Project-Based Learning Learning Video

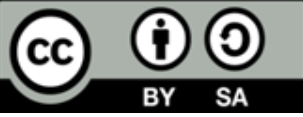

This is an open access article under the CC BY-SA license.

Copyright (C) 2021 by Author. Published by Universitas Pendidikan Ganesha.

\begin{abstract}
A B S T R A K
TIK tidak sekadar untuk dikuasainya pengetahuan dan keterampilan di bidang TIK oleh siswa, melainkan juga kemampuan siswa dalam memecahkan persoalan-persoalan dalam dunia nyata yang memerlukan kehadiran TIK untuk mengatasinya. Akan tetapi, kenyataan di lapangan menunjukkan bahwa siswa belum mampu mengorelasikan materi TIK yang dipelajarinya dengan penyelesaian tugas-tugasnya. Penelitian ini bertujuan untuk menganalisis peningkatan hasil belajar bimbingan TIK siswa kelas IX SMP melalui implementasi model project-based learning berfasilitas media video pembelajaran. Penelitian yang dilaksanakan merupakan penelitian tindakan kelas yang terdiri dari dua siklus. Setiap siklus mengikuti langkah-langkah meliputi: perencanaan, pelaksanaan, observasi, dan refleksi. Adapun subjek PTK ini adalah siswa kelas IXD di SMP Negeri 3 Mengwi sebanyak 31 siswa. Metode penelitian yang digunakan adalah metode tes (kinerja) dengan rubrik penilaian sebagai instrumen penelitian. Data yang terkumpul dianalisis menggunakan teknik analisis statistik deskriptif. Hasil analisis menunjukkan bahwa terjadi peningkatan hasil belajar bimbingan TIK siswa kelas IX SMP melalui implementasi model project-based learning berfasilitas media video pembelajaran. Model project-based learning dapat meningkatkan hasil belajar siswa terlebih dengan difasilitasi oleh media video pembelajaran.
\end{abstract}

\section{ABSTRACT}

ICT is not merely focus on students mastering the knowledge and skill of ICT, but also on students' ability in solving the real-world problems that require the use of ICT. However, the reality showed the students were not able to correlate their learning on ICT with the assigment they have to accompolish their tasks. The current research was aimed to analyze the improvement of students' learning results on ICT mentorship program for grade 9 at junior high school through the implementation of projectbased learning model facilitated by learning video media. This research was classroom action research conducted into two cycles, each cycle consists of the following steps: plan, action, observe, and reflect. The subjects of the research were 31 students of Class IXD at SMP Negeri 3 Mengwi. The research method was performance test and the research instrument was a rubric. The collected data were then analyzed by using descriptive statistical technique. The analysis results showed there was improvement on students' learning results on ICT mentorship program for grade 9 at junior high school through the implementation of project-bassed learning model facilitated by learning video media. Project-bassed learning model can improve students' learning results especially when it is combined with learning video media.

\section{PENDAHULUAN}

Perkembangan Teknologi Informasi dan Komunikasi (TIK) secara nyata berdampak pada berbagai aspek kehidupan manusia, tidak terkecuali pada aspek pendidikan. Integrasi TIK dalam pendidikan ditandai dengan digunakannya berbagai strategi dan produk hasil TIK dalam proses belajar mengajar. Hal ini bertujuan agar out put dan outcome dunia pendidikan khususnya di jenjang SMP dapat menjawab 
tantangan yang ada di masyarakat atau paling tidak dapat mengikuti perkembangan pembelajaran pada level selanjutnya (Razak et al., 2019; Zheng \& Chen, 2021). TIK bukan merupakan mata pelajaran yang berdiri sendiri. TIK sebagai sebuah bentuk program bimbingan di Sekolah Mengenah Pertama (SMP), yang memiliki makna yang luas. Belajar TIK tidak sekadar untuk menguasai pengetahuan dan keterampilan di bidang TIK, melainkan siswa juga perlu menguasai pengetahuan, sikap, dan keterampilan dalam memecahkan persoalan-persoalan dalam dunia nyata yang memerlukan kehadiran TIK untuk mengatasinya. Tuntutan pembelajaran abad 21, yakni kemampuan berpikiran kritis, berkomunikasi, berkreasi, dan berkolaborasi merupakan keterampilan-keterampilan yang harus dimiliki siswa jika ingin survive dan berpartisipasi dalam abad 21 yang juga merupakan era digital. Terlebih di masa new normal akibat Pandemi Covid-19, pembelajaran berbasis TIK yang dapat memaksimalkan kemampuan peserta didik untuk belajar sangat diperlukan (Firmansyah et al., 2021; Reuge et al., 2021; Widyastono, 2015). Bimbingan TIK yang pertama kali diberikan kepada siswa di tingkat SMP bertujuan mengenalkan pengetahuan, sikap, dan keterampilan dasar di bidang TIK. Kompetensi dasar di bidang TIK ini harus dikuasai dengan baik oleh siswa, sehingga mereka dapat menggunakannya untuk mendukung pencapaian kompetensi mata pelajaran lain yang memerlukan peran TIK di dalamnya dan juga dapat menggunakannya dalam kehidupan sehari-hari. Demikian pentingnya penguasaan pengetahuan dan keterampilan TIK bagi siswa SMP, khususnya bgi siswa yang akan segera ke jenjang selanjutnya (kelas X). Oleh karean itu, pembelajaran Bimbingan TIK di kelas IX perlu mendapat perhatian khusus. Namun, kenyataan menunjukkan bahwa pembelajaran Bimbingan TIK di kelas IXD SMP Negeri 3 Mengwi masih terkategori rendah. Hal ini ditunjukkan oleh hasil ulangan harian siswa pada materi membuat flayer di Ms. Power Point. Berdasarkan dokumentasi guru TIK Kelas IXD, diketahui 11 siswa (35\%) memenuhi Kriteria Ketuntasan Minimal (KKM) dan 20 siswa (65\%) masih di bawah KKM. Hal ini menunjukkan bahwa hasil belajar siswa masih tergolong rendah.

Berdasarkan wawancara dengan siswa serta orang tua sebagai pendamping siswa kelas IX D selama belajar daring pada masa pandemi Covid-19, rendahnya hasil belajar siswa ini disebabkan oleh tiga faktor utama. Pertama, siswa senang belajar daring melalui video conference, akan tetapi kendala signal dan teknis lain seperti kuota yang diperlukan menjadi penghambat pelaksanaan video conference secara intensif. Kedua, mengingat pembelajaran yang lebih intens dilakukan melalui pembacaan materi dalam bentuk pdf file dan tugas mengikuti sesudah materi, maka siswa mengerjakan tugas mirip dengan contoh materi meskipun yang ditugaskan menyesuaikan dengan lingkungan siswa. Hal ini menunjukkan siswa kurang mampu mengaplikasikan materi pada kehidupannya sehari-hari. Ketiga, siswa merasa jenuh dan cepat bosan jika pembelajaran hanya sebatas pengiriman materi dan tugas oleh guru. Oleh sebab itu, diperlukan suatu upaya untuk mengatasi permasalahan yang dipaparkan. Permasalahan dalam proses bimbingan TIK perlu dicarikan solusi dengan melakukan inovasi dan pendekatan, sehingga proses bimbingan TIK berlangsung aktif, efektif, dan menyenangkan. Alternatif solusi yang dapat diambil adalah menerapkan pembelajaran daring yang efektif dan inovatif, menggunakan media pembelajaran yang interaktif dan menarik, sehingga siswa tidak merasa bosan dan juga tidak memberatkan siswa dari segi kuota internet (Murni, 2017; Teknologi et al., 2013).

Menerapkan pembelajaran daring yang efektif dan inovatif dapat diawali dengan pemilihan model pembelajaran daring yang efektif dan inovatif pula. Terdapat berbagai model pembelajaran inovatif yang terbukti efektif meningkatkan hasil belajar bimbingan TIK siswa SMP. Model-model pembelajaran inovatif tersebut seperti: think pair share/TPS dan jigsaw (Dianti, N,. P et al., 2016; Kade et al., 2019). Masih banyak lagi model pembelajaran inovatif lainnya yang diyakini dapat memfasilitasi siswa SMP untuk menguasai kompetensi pada bimbingan TIK secara daring. Salah satu model pembelajaran dimaksud yang diyakini dapat memfasilitasi belajar siswa secara efektif dan inovatif adalah model project-based learning atau pembelajaran berbasis proyek. Project-based learning merupakan model pembelajaran yang berpusat pada peserta didik (student-centered) yang memberikan pengalaman belajar yang bermakna bagi peserta didik berupa terbentuknya suatu konsep pada diri siswa yang dibangun berdasarkan produk yang dihasilkan dalam pembelajaran, sehingga siap menghadapi lingkungan kerja masa depan (Li et al., 2017; Sumarmi et al., 2021). Project-based learning dapat mengaktifkan siswa dan memberikan mereka kesempatan untuk bekerja secara mandiri serta mendapatkan catatan menarik yang membantu mereka memahami materi melalui proses pemecahan masalah untuk menyelesaikan proyek (Dwiyani Putri et al., 2019; Rahayu \& Sukardi, 2021). Berikut gambaran langkah-langkah pembelajaran dengan menerapkan model project-based learning: (1) penentuan pertayaan mendasar/start with essential questions), (2) mendesain perencanaan proyek/design a plan for the project, (3) menyusun jadwal/create a schedule, (4) memonitor siswa dan kemajuan proyek/monitor the students and the progress of the project), (5) menguji hasil/assess the outcome, dan (6) mengevaluasi pengalaman/evaluate the experience (Falkhi, 2017; Sakulviriyakitkul et al., 2020).

Model project-based learning diyakini akan lebih efektif lagi jika difasilitasi dengan media 
pembelajaran yang disiapkan guru bimbingan TIK untuk mendampingi siswa selama mengerjakan proyek (Al-Abdullatif \& Gameil, 2021; Štemberger \& Čotar Konrad, 2021). Media-media yang selama ini terbukti efektif digunakan untuk memfasilitasi siswa dalam belajar pada program bimbingan TIK seperti: media komputer tutorial, media video pembelajaran (Lestari et al., 2020; Siska et al., 2020). Mempertimbangkan keefektifan media komputer turotial dan media video pembelajaran, maka pada penelitian ini pembelajaran siswa pada bimbingan TIK difasilitasi oleh media video pembelajaran berformat video tutorial. Pemanfaatan video pembelajaran yang sesuai dengan karakteristik peserta didik dapat meningkatkan hasil belajar karena video pembelajaran dapat meningkatkan minat dalam belajar mengingat video pembelajaran mengandung gambar dan suara yang memotivasi peserta didik untuk mau bertanya serta meningkatkan pengetahuan (Maulana et al., 2019; Okta Priantini, 2021). Media video pembelajaran yang berisi panduan lengkap step-by-step menyelesaikan proyek dapat diunduh dan diputar kembali selama siswa membutuhkan, sehingga tidak memerlukan kuota yang banyak seperti halnya jika materi disimak via video conference. Mengacu paparan di atas, pada penelitian ini dicoba melakukan inovasi untuk meningkatkan hasil belajar bimbingan TIK siswa kelas IXD di SMP Negeri 3 Mengwi melalui implementasi project-based learning berfasilitas media video pembelajaran. Adapun tujuan dilaksanakannya penelitian ini adalah untuk menganalisis peningkatan hasil belajar bimbingan TIK siswa kelas IXD SMP Negeri 3 Mengwi melalui implementasi model project-based learning berfasilitas media video pembelajaran pada semester genap tahun pelajaran 2020/2021.

\section{METODE}

Penelitian ini merupakan Penelitian Tindakan Kelas (PTK) atau classroom action research. PTK ini didesain dan dilaksanakan mengacu pada siklus PTK Kemmis dan Taggart yang terdiri dari empat tahap kegiatan: perencanaan/plan, tindakan/action, pengamatan/ observation, dan refleksi/ reflection (Manfra, 2019; Salleh \& Aiman, 2015). Penetapan siklus dalam sebuah PTK didasari oleh kriteria keberhasilan PTK, ada yang dua siklus, tiga siklus bahkan lebih (Bangun, 2018; Panjaitan, 2018). Berdasarkan siklus PTK yang dirujuk, adapun prosedur PTK ini adalah sebagai berikut. Pada siklus I, perencanaan (plan) terdiri dari kegiatan persiapan pelaksanaan penelitian, meliputi: penentuan jadwal pelaksanaan siklus I dan penyiapan rencana perangkat bimbingan (RPB) dengan model project-based learning, media video pembelajaran, instrumen penilaian). Pelaksanaan (action) berisi kegiatan implementasi project-based learning selama 3 kali pertemuan mengacu pada sintaks/langkah-langkah project-based learning untuk penyelesaian sebuah proyek. Pengamatan (observation) dilakukan terhadap pelaksanaan project-based learning dan didokumentasikan sebagai bahan refleksi untuk pelaksanaan siklus I serta menentukan hasil belajar setiap siswa. Refleksi (Reflection) berisi kegiatan seleksi, penyederhanaan dan pengklasifikasian data secara sistematik untuk selanjutnya dibahas hal-hal yang perlu dipertahankan, ditingkatkan atau ditinggalkan. Hasil refleksi siklus I dijadikan dasar dalam perbaikan perencanaan pembelajaran pada siklus 2 .

Pada siklus II, perencanaan (plan) yang dilakukan meliputi berbagai persiapan pelaksanaan penelitian siklus II, meliputi: penentuan jadwal pelaksanaan siklus II dan penyiapan perangkat pembelajaran yang disusun berdasarkan refleksi Siklus I (RPB dengan model project-based learning, media video pembelajaran, instrumen penilaian). Pelaksanaan (action) meliputi kegiatan implementasi project-based learning selama 3 kali pertemuan mengacu pada sintaks/langkah-langkah project-based learning untuk penyelesaian sebuah proyek dengan perbaikan pelaksanaan pembelajaran mengacu pada RPB siklus II. Pengamatan (observation) dilakukan terhadap pelaksanaan project-based learning dan didokumentasikan sebagai bahan refleksi pelaksanaan siklus II serta menentukan hasil belajar setiap siswa. Refleksi (reflection) dilakukan dengan menseleksi, menyederhanakan dan mengklasifikasikan data observasi secara sistematik sebagai bahan untuk membahas hal-hal yang perlu dipertahankan, ditingkatkan ,atau ditinggalkan. Hasil refleksi dijadikan dasar dalam perbaikan perencanaan pembelajaran pada penelitian selanjutnya. PTK ini dihentikan sampai siklus ke-2 mengingat hasil belajar siswa pada siklus ke-2 telah memenuhi kriteria keberhasilan yang dijadikan acuan dalam penelitian ini yakni nilai yang diperoleh siswa $\geq 70$. Hasil belajar tersaji secara detail pada hasil penelitian.

PTK ini melibatkan seluruh siswa di kelas IXD sebagai subjek penelitian. Jumlah siswa kelas IXD adalah 31 siswa, terdiri dari 17 siswa perempuan dan 14 siswa laki-laki. Penelitian ini dilaksanakan di SMP Negeri 3 Mengwi. Mengingat pembelajaran berlangsung daring, maka penelitian dilaksanakan secara daring mengacu pada model pembelajaran yang diimplementasikan. Waktu pelaksanaan penelitian ini adalah pada semester genap tahun pelajaran 2020/2021 selama dua (2) bulan yakni dimulai dari Bulan Januari sampai dengan pertengahan Bulan Maret 2021. Penelitian ini melibatkan satu variabel bebas dan satu variabel terikat. Variabel bebas dalam penelitian ini adalah implementasi project-based learning berfasilitas media video pembelajaran, sedangkan variabel terikatnya adalah hasil belajar bimbingan TIK. 
Secara konseptual project-based learning berfasilitas media video pembelajaran adalah model pembelajaran berbasis proyek yang mengarahkan siswa untuk membangun pengetahuannya sendiri dengan pemberian tantangan atau masalah yang diselesaikan melalui proses pengerjaan proyek dan menghasilkan produk sebagai wujud perolehan konsep dan pengalaman bermakna siswa dengan difasilitasi media video pembelajaran. Hasil belajar bimbingan TIK adalah perubahan tingkah laku siswa setelah mengikuti kegiatan bimbingan TIK yang diukur dengan alat ukur yang sesuai.

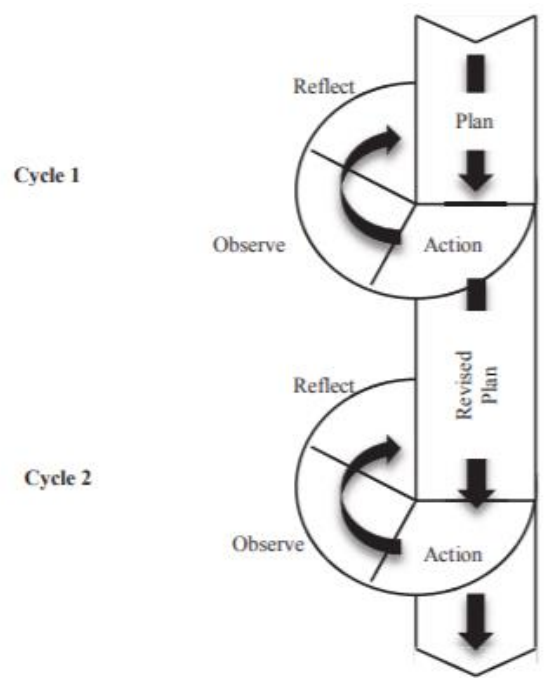

Gambar 1. Desain PTK Kemmis dan Taggart

Secara operasional Project-based learning berfasilitas media video pembelajaran adalah model pembelajaran yang terdiri dari lima sintaks/langkah-langkah pembelajaran sistematis: (1) penentuan pertayaan mendasar (start with essential questions), (2) mendesain perencanaan proyek (design a plan for the project), (3) menyusun jadwal (create a schedule), (4) memonitor siswa dan kemajuan proyek (monitor the students and the progress of the project), (5) menguji hasil (assess the outcome), (6) mengevaluasi pengalaman (evaluate the experience). Dalam penerapan sintaksnya difasilitasi oleh penggunaan media video pembelajaran khususnya sintaks keempat. Hasil belajar bimbingan TIK adalah perubahan tingkah laku siswa setelah mengikuti kegiatan bimbingan TIK yang diukur dengan alat ukur berupa rubrik praktik/proses pengerjaan proyek dan rubrik produk hasil proyek. Metode pengumpulan data yang digunakan dalam penelitian ini adalah metode tes kinerja (performance test). Metode tes kinerja digunakan untuk memperoleh data hasil belajar bimbingan TIK dengan cara menilai praktik dan produk siswa. Dipilihanya metode tes kinerja dalam penelitian ini didasari oleh rasional bahwa tes kinerja merupakan salah satu bentuk penilaian autentik karena lebih bermakna dibandingkan dengan tes pilihan ganda terstandar sekalipun. Untuk menilai kinerja siswa, tidak hanya dari produk melainkan pula dari proses/keterampilan siswa mengerjakan proyek untuk menghasilkan produk (Wildan, 2017; Wulandari, 2016). Berdasarkan metode pengumpulan data, selanjutnya dikembangkan instrumen berupa rubrik penilaian kinerja dengan mengacu pada kisi-kisi pada Tabel 1.

Tabel 1. Kisi-kisi Rubrik Penilaian Kinerja Project-Based Learning Bimbingan TIK

\begin{tabular}{|c|c|c|}
\hline No & Aspek & Indikator \\
\hline \multirow[t]{5}{*}{$\mathrm{I}$} & Penilaian Proses & 1. Keaktifan dalam mengerjakan proyek \\
\hline & & 2. Motivasi mengerjakan proyek \\
\hline & & $\begin{array}{l}\text { 3. Kemampuan menerapkan konsep-konsep TIK dalam } \\
\text { mengerjakan proyek }\end{array}$ \\
\hline & & 4. Tanggung jawab menyelesaikan proyek \\
\hline & & $\begin{array}{l}\text { 5. Kedisiplinan yang ditandai dengan ketepatan waktu } \\
\text { menyelesaikan proyek }\end{array}$ \\
\hline \multirow[t]{5}{*}{ II } & Penilaian Produk & 1. Ide/gagasan produk \\
\hline & & 2. Komposisi produk \\
\hline & & 3. Kreativitas produk \\
\hline & & 4. Kerapihan produk \\
\hline & & 5. Kemenarikan produk \\
\hline
\end{tabular}


Berdasarkan kisi-kisi tersebut selanjutnya dikembangkan instrumen penelitian berupa rubrik penilaian kinerja yang dilengkapi dengan pedoman penskoran. Sebelum digunakan, insrumen penelitian ini divalidasi isi oleh dua orang pakar yang merupakan guru profesional di bidang bimbingan TIK di Kabupaten Badung. Berdasarkan analisis validitas isi menggunakan teknik analisis Gregory diperoleh hasil validitas instrumen penelitian sebesar 0,9 (kriteria sangat tinggi). Teknik penilaian hasil belajar bimbingan TIK siswa menggunakan rubrik penelitian yang valid tersebut dilakukan dengan metode digital assessmen. Hal ini didasari oleh penelitian sebelumnya yang menunjukkan bahwa instrumen penilaian kinerja digital mendapatkan hasil yang lebih baik jika dibandingkan dengan penggunaan penilaian kinerja manual (Muhammad et al., 2018; Nuryati et al., 2020). Data-data yang terkumpul dianalisis menggunakan teknik analisis statistika deskriptif. Hasil PTK yang lebih baik diperoleh setelah mengimplementasikan ilmu statistika didalamnya (Irhamah et al., 2018) Artinya, data hasil penelitian disajikan melalui deskripsi angka-angka yang meliputi deskripsi dalam bentuk mean, modus, median dan standar deviasi dari data di setiap siklusnya. Data-data yang terkumpul dalam penelitian ini dianalisis menggunakan bantuan aplikasi Ms. Office Excel.

\section{HASIL DAN PEMBAHASAN}

\section{Hasil}

Data hasil belajar bimbingan TIK siswa kelas IXD setelah implementasi model project-based learning berfasilitas media video pembelajaran pada siklus I adalah sebagai berikut. Mean (M) sebesar 71,97, median (Me) adalah 76,66, modus (Mo) adalah 53,21, dan standar deviasi (SD) adalah 14,02. Data hasil belajar bimbingan TIK siswa kelas IXD pada siklus II adalah sebagai berikut. Mean sebesar 81,45, median adalah 81,74 modus adalah 90,37 dan standar deviasi adalah 7,38. Berdasarkan hasil penelitian di siklus II yakni hasil belajar bimbingan TIK siswa kelas IXD SMP Negeri 3 Mengwi telah memenuhi kriteria penilaian $\geq 70$, maka penelitian dihentikan sampai dengan siklus ke-2. Berdasarkan data pada siklus II, rata-rata hasil bimbingan TIK siswa kelas IXD setelah implementasi model project-based learning berfasilitas media video pembelajaran adalah sebesar 81,45. Hasil ini meningkat dari rata-rata hasil bimbingan TIK kelas IXD pada siklus I yakni sebesar 71,97. Peningkatan dimaksud adalah sebesar 9,48. Selain dari hasil rata-rata nilai (mean), peningkatan juga dapat dilihat dari perubahan nilai median dan modus data pada siklus I dan siklus II. Di samping itu, simpangan baku/ standar deviasi (SD) data pada siklus I dan Siklus II mengalami penurunan, dari 14,02 menjadi sebesar 7,38 yang berarti bahwa perbedaan nilai yang terjadi antara sampel dan rata-rata semakin kecil.

\section{PEMBAHASAN}

Melalui penelitian ini, project-based learning secara empiris telah menunjukkan bahwa hasil belajar, khususnya bimbingan TIK siswa menjadi meningkat. Temuan penelitian ini menunjukkan pula bahwa project-based learning telah mampu melibatkan siswa dalam pembelajarannya. Temuan ini sejalan dengan penelitian lainnya yang menyatakan bahwa project-based learning merupakan jalan dalam melibatkan siswa untuk aktif dalam pembelajarannya. Keterlibatan aktif siswa ini, di samping terlihat pada hasil akhir (output) pembelajaran, juga tampak pada proses pembelajaran yang menunjukkan pembelajaran yang bersifat autentik (Almulla, 2020; Maros et al., 2021). Secara detail pembelajaran yang bersifat autentik tersebut dapat dibahas melalui pelaksanaan pembelajaran di setiap siklusnya. Hasil yang cukup mengembirakan ini disebabkan oleh penerapan model project-based learning berfasilitas media video pembelajaran memberikan peluang kepada siswa untuk mengembangkan kemampuan dan kreativitasnya dalam memanfaatkan TIK. Siswa membangun pengetahuannya sendiri melalui penyelesaian tugas berupa proyek yang dirancang sendiri oleh siswa yang diawali dengan pemberian pertanyaan yang mendasar oleh guru. Belajar melalui pengerjaan proyek secara langsung dapat meningkatkan motivasi siswa (Hapsari \& Airlanda, 2019; Sari, 2018). Semua siswa aktif dalam pembelajaran/learning to do, semua siswa bekerja sama secara kelompok dengan baik/learning to live together, sehingga pembahasan hasil pengerjaan proyek lebih lengkap/learning to be. Di samping itu, penggunaan media dapat meningkatkan pemahaman siswa terhadap apa yang perlu diketahui untuk dapat mengerjakan proyeknya/learning to know (Handayani, 2020; I. A. Pratiwi et al., 2018).

Namun, disadari bahwa peningkatan hasil bimbingan TIK pada siklus I ini belum optimal. Dapat dianalisis beberapa hal yang menyebabkan belum optimalnya hasil belajar siswa pada siklus I. Hal ini dapat diketahui melalui tahap evaluasi pengalaman siswa pada sintaks model project-based learning dan juga pada tahap refleksi pelaksanaan PTK Siklus I. Pertama, pada tahap awal pelaksanaan sintaks model project-based learning yakni penentuan pertayaan mendasar, jenis pertanyaan yang diberikan di awal oleh guru masih sedikit membingungkan siswa. Hal ini terjadi karena pertanyaan yang diberikan guru diorientasikan untuk memotivasi siswa agar belajar menyelesaikan sendiri melalui penugasan yang 
diberikan. Cara seperti ini belum biasa dilakukan oleh siswa pada pembelajaran-pembelajaran sebelumnya. Kedua, pada tahap mendesain perencanaan proyek, siswa masih ragu menetapkan ide sendiri untuk mewujudkan tugas melalui pengerjaan proyek, sehingga siswa diberi masukan-masukan oleh guru. Ketiga, pada tahap menyusun jadwal, siswa tidak mengalami kesulitan yang berarti, namun siswa mengalami kesulitan dalam mematuhi jadwal yang telah disepakati tersebut, sehingga siswa sering diingatkan oleh guru. Keempat, guru mengalami sedikit perubahan teknis terkait proses memonitoring kemajuan siswa akibat terdapatnya 10 orang siswa yang tidak dapat mengikuti jadwal yang telah mereka tetapkan pada tahapan sebelumnya. Berdasarkan kelemahan-kelamahan yang ada pada implementasi model project-based learning berfasilitas media video pembelajaran pada bimbingan TIK siswa kelas IXD SMP Negeri 3 Mengwi tersebut, selanjutnya dilakukan upaya-upaya perbaikan di siklus II. Hasil penelitian pada siklus II menunjukkan hasil yang sangat mengembirakan. Seluruh siswa terkategori tuntas mempelajari materi "Membuat animasi di program aplikasi Ms. Power Point agar presentasi terlihat lebih menarik". Upaya-upaya perbaikan kelemahan pada siklus I yang dilakukan pada siklus II terbukti efektif. Keefektifan ini didukung oleh beberapa hal berikut. Pertama, siswa sudah terbiasa menyimak pertanyaan guru di awal pembelajaran dan tidak tergesa-gesa menjawab. Pertanyaann tersebut sebatas pemahaman teoretis dari buku. Siswa sudah mulai berpikir lebih jauh terhadap pertanyaan guru secara kritis. Hal ini senada dengan temuan penelitian-penelitian sebelumnya yang menemukan bahwa berpikir kreatif dan pemecahan masalah siswa menjadi lebih baik setelah penerapan project-based learning (E. T. Pratiwi \& Setyaningtyas, 2020; Rahmazatullaili et al., 2017). Kedua, siswa sudah mampu menetapkan sendiri proyek yang akan dikerjakannya. Selain itu pula, video pembelajaran yang disiapkan guru dapat memfasilitasi siswa untuk berkreasi sesuai idenya masing-masing dalam menyelesaikan proyek. Hal ini menandakan bahwa siswa telah terlibat aktif dalam pembelajaran daring yang diikutinya (Martin \& Bolliger, 2018). Pada siklus II ini siswa mampu mengikuti jadwal penyelesaian proyek yang telah disepakati, sehingga guru dapat memantau kemajuan siswa sesuai jadwal untuk kemudian dinilai dan dievaluasi bersama pengalaman yang telah diperoleh siswa masing-masing. Ketiga, berdasarkan evaluasi pengalaman belajar pada sintaks keenam project-based learning, diketahui bahwa semua siswa menyatakan senang mengikuti pembelajaran dengan implementasi project-based learning berfasilitas media video pembelajaran. Meskipun siswa menyatakan terdapat kesulitan menetapkan proyek yang akan dikerjakan, siswa merasa tertantang untuk mencari ide dari proyek dan menyelesaikan proyek tersebut tepat waktu. Pendampingan guru berupa pemberian video pembelajaran dan adanya tahap monitoring kemajuan proyek siswa dirasakan siswa sangat membantu mereka untuk rajin mengerjakan proyek tepat waktu. Di samping memberikan fungsi tutor untuk mengarahkan penyelesaian proyek secara kontekstual, penggunaan media pembelajaran dalam implementasi project-based learning dapat meningkatkan kemampuan berpikir kritis siswa untuk menyelesaikan kesulitan yang ditemui pada saat mengerjakan proyek (Amamou \& Cheniti-Belcadhi, 2018; Pratama \& Prastyaningrum, 2016) . PTK ini telah memberikan tambahan wawasan dan praktik, baik pelaksanaan pembelajaran TIK secara daring bagi siswa kelas IXD SMP Negeri 3 Mengwi pada khususnya maupun keluarga besar SMP Negeri 3 Mengwi pada umumnya. Implikasi penelitian ini terlihat pada pelaksanaan pembelajaran bimbingan TIK yang aktif dan melalui arahan kepala sekolah serta kinerja maksimal para guru, SMP Negeri 3 Mengwi yang senantiasa berupaya memfasilitasi siswa semaksimal mungkin dalam belajar secara daring. Disadari bahwa PTK ini masih memiliki keterbatasan dan hanya fokus pada peningkatan hasil belajar siswa. Berikutnya, diharapkan dapat diteliti lebih lanjut aspek pembelajaran lain secara spesifik seperti minat belajar siswa, pola asuh orang tua, variasi media pembelajaran dan aspek pembelajaran daring lainnya.

\section{SIMPULAN}

Implementasi model project-based learning berfasilitas media video pembelajaran yang efektif dapat meningkatkan hasil belajar bimbingan TIK siswa. Keefektifan model project-based learning dalam implementasinya merujuk pada sintaks pembelajaran dan integrasinya dengan media video pembelajaran.

\section{DAFTAR RUJUKAN}

Al-Abdullatif, A. M., \& Gameil, A. A. (2021). The Effect of Digital Technology Integration on Students' Academic Performance through Project-Based Learning in an E-learning Environment. International Journal of Emerging Technologies in Learning (IJET), 16(11), 189. https://doi.org/10.3991/ijet.v16i11.19421.

Almulla, M. A. (2020). The Effectiveness of the Project-Based Learning (PBL) Approach as a Way to Engage Students in Learning. SAGE Open, 10(3). https://doi.org/10.1177/2158244020938702. 
Amamou, S., \& Cheniti-Belcadhi, L. (2018). Tutoring In Project-Based Learning. Procedia Computer Science, 126, 176-185. https://doi.org/10.1016/j.procs.2018.07.221.

Bangun, B. K. (2018). Improving Students' Speaking Skill by Using Show and Tell Method: A Classroom Action Research. International Journal of Language Teaching and Education, 2(1), 41-48. https://doi.org/10.22437/ijolte.v2i1.4517.

Dianti, N,. P, S., Agustini, K., \& Sugihartini, N. (2016). Studi Komparatif Penggunaan Model Pembelajaran Think Pair Square dan Teams Games Tournament terhadap Motivasi dan Hasil Belajar TIK Siswa Kelas VIII SMP N 1 Sawan Tahun Ajaran 2015/2016. Kumpulan Artikel Mahasiswa Pendidikan Teknik Informatika, 5(2).

Dwiyani Putri, G. A. M., Rati, N. W., \& Mahadewi, L. P. P. (2019). Pengaruh Model Pembelajaran Berbasis Proyek terhadap Hasil Belajar IPA. Journal of Education Technology, 3(2), 65. https://doi.org/10.23887/jet.v3i2.21705.

Falkhi, Q. (2017). Konsep dan Sintak Problem Based Learning. Www. Pembelajaran.Id, 1-7. http://www.pembelajaran.id/2017/05/konsep-dan-sintak-problem-based-learning.html.

Firmansyah, R., Putri, D. M., Wicaksono, M. G. S., Putri, S. F., Widianto, A. A., \& Palil, M. R. (2021). Educational Transformation: An Evaluation of Online Learning Due To COVID-19. International Journal of Emerging Technologies in Learning (IJET), 16(07), 61. https://doi.org/10.3991/ijet.v16i07.21201.

Handayani, L. (2020). Peningkatan Motivasi Belajar IPA Melalui Model Pembelajaran Project Based Learning pada Masa Pandemi Covid-19 bagi Siswa SMP Negeri 4 Gunungsari. Jurnal Paedagogy, 7(3), 168. https://doi.org/10.33394/jp.v7i3.2726.

Hapsari, D. I., \& Airlanda, G. S. (2019). Penerapan Project Based Learning untuk Meningkatkan Motivasi Belajar Matematika. Jurnal Riset Teknologi Dan ..., 2(1), 102-112. http://journal-litbangrekarta.co.id/index.php/jartika/article/view/155.

Irhamah, I., Mukarromah, A., Mukarromah, A., Winahju, W. S., Winahju, W. S., Fithriasari, K., Fithriasari, K., \& Oktaviana, P. P. (2018). Implementasi Model Riset Statistika untuk Peningkatan PTK bagi Kelompok Kerja Pengawas PAI/Madrasah Kankemenag Kabupaten Jombang. SEWAGATI, 2(2), 7075. https://doi.org/10.12962/j26139960.v2i2.4552.

Kade, A., Degeng, I. N. S., \& Ali, M. N. (2019). Effect of Jigsaw Strategy and Learning Style to Conceptual Understanding on Senior High School Students. International Journal of Emerging Technologies in Learning (IJET), 14(19), 4. https://doi.org/10.3991/ijet.v14i19.11592.

Lestari, A., Suryadi, A., \& Ismail, A. (2020). Pengaruh Media Pembelajaran Berbasis Komputer dengan Model Tutorial untuk Meningkatkan Hasil Belajar Siswa pada Mata Pelajaran TIK. JURNAL PETIK, 6(1), 18-26. https://doi.org/10.31980/jpetik.v6i1.729.

Li, Y.-X., Lai, H.-M., \& Chen, C.-P. (2017). A Scientometric Review of the Current Status and Emerging Trends in Project-Based Learning. International Journal of Information and Education Technology, 7(8), 581-584. https://doi.org/10.18178/ijiet.2017.7.8.935.

Manfra, M. M. (2019). Action Research and Systematic, Intentional Change in Teaching Practice. Review of Research in Education, 43(1), 163-196. https://doi.org/10.3102/0091732X18821132.

Maros, M., Korenkova, M., Fila, M., Levicky, M., \& Schoberova, M. (2021). Project-Based Learning and Its Effectiveness: Evidence from Slovakia. Interactive Learning Environments, $0(0), 1-9$. https://doi.org/10.1080/10494820.2021.1954036.

Martin, F., \& Bolliger, D. U. (2018). Engagement Matters: Student Perceptions on the Importance of Engagement Strategies in the Online Learning Environment. Online Learning, 22(1), 205-222. https://doi.org/10.24059/olj.v22i1.1092.

Maulana, A., Sekartaji, G. T., Arthur, R., \& Dewi, L. K. (2019). Pengembangan Media Video Presentasi pada Mata Kuliah Hidrologi di Universitas Negeri Jakarta. Kwangsan: Jurnal Teknologi Pendidikan, 7(2), 170. https://doi.org/10.31800/jtp.kw.v7n2.p170--183.

Muhammad, A., Lebar, O., \& Mokshein, S. E. (2018). Rubrics as Assessment, Evaluation and Scoring Tools. International Journal of Academic Research in Business and Social Sciences, 8(10), 1417-1431. https://doi.org/10.6007/IJARBSS/v8-i10/5309.

Murni, M. (2017). Kemampuan dan Hasil Belajar TIK Materi Microsoft Excel Melalui Proyektor LCD Siswa Kelas VIII.D SMP. Manajemen Pendidikan, 12(1), 10. https://doi.org/10.23917/jmp.v12i1.2971.

Nuryati, D. W., Masitoh, S., \& Arianto, F. (2020). Pengaruh Project Based Learning terhadap Kreativitas Peserta Didik di Masa Pandemi. Educate: Jurnal Teknologi Pendidikan, 5(2), 98-106. https://doi.org/10.32832/educate.v5i2.3375.

Okta Priantini, D. A. M. M. (2021). The Development Of Teaching Video Media Based On Tri Kaya Parisudha In Educational Psychology Courses. Journal of Education Technology, 4(4), 448. https://doi.org/10.23887/jet.v4i4.29608. 
Panjaitan, D. J. (2018). Peningkatan Pemahaman dan Aplikasi Konsep melalui Pendekatan Contextual Teaching and Learning. Jurnal MathEducation Nusantara, 1(1), 52-59.

Pratama, H., \& Prastyaningrum, I. (2016). Pengaruh Model Pembelajaran Project Based Learning Berbantuan Media Pembelajaran Pembangkit Listrik Tenaga Mikrohidro Terhadap Kemampuan Berpikir Kritis. Jurnal Penelitian Fisika Dan Aplikasinya (JPFA), 6(2), 44. https://doi.org/10.26740/jpfa.v6n2.p44-50.

Pratiwi, E. T., \& Setyaningtyas, E. W. (2020). Kemampuan Berpikir Kritis Siswa melalui Model Pembelajaran Problem Based Learning dan Model Pembelajaran Project Based Learning. Jurnal Basicedu, 4(2), 379-388. https://doi.org/10.31004/basicedu.v4i2.362.

Pratiwi, I. A., Ardianti, S. D., \& Kanzunnudin, M. (2018). Peningkatan Kemampuan Kerjasama melalui Model Project Based Learning (PjBL) Berbantuan Metode Edutainment pada Mata Pelajaran Ilmu Pengetahuan Sosial. Refleksi Edukatika: Jurnal Ilmiah Kependidikan, 8(2). https://doi.org/10.24176/re.v8i2.2357.

Rahayu, I., \& Sukardi, S. (2021). The Development Of E-Modules Project Based Learning for Students of Computer and Basic Networks at Vocational School. Journal of Education Technology, 4(4), 398. https://doi.org/10.23887/jet.v4i4.29230.

Rahmazatullaili, R., Zubainur, C. M., \& Munzir, S. (2017). Kemampuan Berpikir Kreatif dan Pemecahan Masalah Siswa melalui Penerapan Model Project Based Learning. Beta: Jurnal Tadris Matematika, 10(2), 166-183. https://doi.org/10.20414/betajtm.v10i2.104.

Razak, N. A., Ab Jalil, H., \& Ismail, I. A. (2019). Challenges in ICT Integration among Malaysian Public Primary Education Teachers: The Roles of Leaders and Stakeholders. International Journal of $\begin{array}{lllll}\text { Emerging Technologies in Learning (IJET), } & 184 .\end{array}$ https://doi.org/10.3991/ijet.v14i24.12101.

Reuge, N., Jenkins, R., Brossard, M., Soobrayan, B., Mizunoya, S., Ackers, J., Jones, L., \& Taulo, W. G. (2021). Education Response to COVID 19 Pandemic, a Special Issue Proposed by UNICEF: Editorial Review. International Journal of Educational Development, 87(August), 102485. https://doi.org/10.1016/j.ijedudev.2021.102485.

Sakulviriyakitkul, P., Sintanakul, K., \& Srisomphan, J. (2020). The Design of a Learning Process for Promoting Teamwork using Project-Based Learning and the Concept of Agile Software Development. International Journal of Emerging Technologies in Learning (IJET), 15(03), 207. https://doi.org/10.3991/ijet.v15i03.10480.

Salleh, N. M., \& Aiman, M. S. (2015). Improving the Quality of Pupils' Response in Science Inquiry Teaching: a Participatory Action Research. Procedia - Social and Behavioral Sciences, 191(January), 13101316. https://doi.org/10.1016/j.sbspro.2015.04.482.

Sari, I. K. (2018). The Effect of Problem-Based Learning and Project-Based Learning on the Achievement Motivation. Jurnal Prima Edukasia, 6(2), 129-135. https://doi.org/10.21831/jpe.v6i2.17956.

Siska, J., Selviani, D., \& Herianto, A. (2020). Pemanfaatan Media Berbasi Video terhadap Hasil Belajar Siswa pada Mata Pelajaran TIK di SMP Negeri 14 Bengkulu Tengah. Journal of Dehasen Educational Review, 1(2), 93-97. https://doi.org/10.33258/jder.v1i2.1046.

Štemberger, T., \& Čotar Konrad, S. (2021). Attitudes towards using Digital Technologies in Education as an Important Factor in Developing Digital Competence: The Case of Slovenian Student Teachers. International Journal of Emerging Technologies in Learning (IJET), 16(14), 83. https://doi.org/10.3991/ijet.v16i14.22649.

Sumarmi, S., Bachri, S., Irawan, L. Y., Aliman, M., \& Wan Ahmad, W. I. (2021). Project-Based Research Learning (PBRL) Integrated With E-Learning in Projects Completion. International Journal of Emerging Technologies in Learning (IJET), 16(07), 16. https://doi.org/10.3991/ijet.v16i07.21193.

Widyastono, H. (2015). Pendayagunaan Teknologi Informasi dan Komunikasi (TIK) Dalam Pengembangan Pembelajaran dan Manajemen Sekolah Rintisan Penerapan Kurikulum 2013. Jurnal Kwangsan, 3(2), 77. https://doi.org/10.31800/jurnalkwangsan.v3i2.26.

Wildan, W. (2017). Pelaksanaan Penilaian Autentik Aspek Pengetahuan, Sikap dan Keterampilan di Sekolah atau Madrasah. Jurnal Tatsqif, 15(2), 131-153. https://doi.org/10.20414/jtq.v15i2.3.

Wulandari, F. E. (2016). Pengaruh Model Pembelajaran Berbasis Proyek untuk Melatihkan Keterampilan Proses Mahasiswa. PEDAGOGIA: Jurnal Pendidikan, 5(2), 247. https://doi.org/10.21070/pedagogia.v5i2.257.

Zheng, Y., \& Chen, I.-H. (2021). The Relation between ICT Usage and 15-Year-Old Students' Science SelfEfficacy. International Journal of Information and Education Technology, 11(2), 88-95. https://doi.org/10.18178/ijiet.2021.11.2.1494. 